\title{
A re-investigation of the instability at the $y v$ locus in tomato
}

\author{
ELLEN WISMAN $\uparrow \&$ M. S. RAMANNA* \\ Department of Plant Breeding, Agricultural University, PO Box 386, NL-6700 AJ, Wageningen, The Netherlands and \\ $\dagger$ Department of Molecular Biology, Agricultural University, Dreyenlaan 3, NL-6703 HA, Wageningen, The Netherlands
}

\begin{abstract}
The instability at the $y v$ locus on chromosome 6 of Lycopersicon esculentum has been re-investigated. Cytogenetic analysis of green, green-yellow variegated and yellow plants showed that the instability is not caused by the somatic segregation of extra chromosomal fragments as was proposed earlier by Hagemann. Instead, it is postulated that the variegated line carries an unstable recessive allele of $y v\left(y v^{m u t}\right)$ that mutates frequently from dominant green to recessive yellow on the basis of the following observations: (i) variegated plants produced variegated and yellow offspring in aberrant ratios, and (ii) yellow male sterile plants appeared in populations derived from crosses of the $\mathrm{Yv}^{\mathrm{ms}}$ line with wild-type plants and the line LA 780, being recessive $y v$. Using the isozyme marker Aps-1 linked to $y v$, it was shown that the deficit in variegated and yellow mutants, which frequently occurs in $\mathrm{F}_{2}$ populations derived from crosses between the variegated mutant and wildtype $y v^{+}$plants, was due to certation. From the analysis of these $\mathrm{F}_{2}$ populations, it is concluded that the instability at $y v$ is likely to be controlled autonomously. No evidence was obtained showing germinal reversion events to occur, as inferred from the absence of green plants among the selfed offspring. Variegated offspring were produced by a yellow plant which is interpreted to represent a somatic reversion event from yellow to variegated. Remarkably, when variegated plants were crossed to wild-type plants, $F_{1}$ plants with a mutant phenotype appeared. On the basis of analogies with mutable alleles from maize and Drosophila, alternative mechanisms underlying the mutability of $y v$ are discussed.
\end{abstract}

Keywords: chromosomal fragments, heterochromatin, Lycopersicon esculentum, transposable elements, unstable $y v$ mutant.

\section{Introduction}

Genes interrupted by transposable elements commonly show a high instability owing to the frequent excision of the element out of the gene. When cell-autonomous traits such as pigmentation or chlorophyll production are involved, somatic instability gives rise to the variegated patterns so often noticeable in flowers, kernels and leaves (Nevers et al., 1986). In fact, variegation is one of the important features through which insertion mutations have been recognized. In addition to transposable elements, variegation has also been attributed to several other causes, including chimerism, virus infection, instability of (additional) chromosomal fragments, nutritional deficiencies (Kirk \& Tilney-Bassett, 1978) and monogenic mutations (Martínez-Zapater et al., 1992).

\footnotetext{
${ }^{*}$ Correspondence.
}

Nevers et al. (1986) formulated a set of general rules to allow insertion mutations to be identified on the basis of genetic criteria. These include: (i) usually wildtype spots appear on a recessive background, indicating that the phenotypic switch is from recessive to dominant, (ii) segregation of the unstable character obeys the laws of Mendel, although stable recessives and wild-type revertants frequently arise as a result of the (im)precise excision of the element, (iii) new alleles are generated with heritable altered phenotypes, and (iv) in some instances a second factor is required for the instability. Examples of the latter are to be found among the two-component systems such as $A c /$ $D s$ and Spm/dSpm in Zea mays, where the autonomous element is capable of transactivating the non-autonomous element integrated at the locus responsible for the variegated phenotype. A number of specific mutants are known in which variegation is associated with transposable element insertions, although the phenotypic switch is from dominant to recessive 
(reverse variegation) (Nevers et al., 1986). In some of these instances it has been shown that wild-type expression of genes carrying an insertion of a transposable element occurred, due to the splicing of the element from the transcript. Null sectors on wild type background can then appear following the incorrect excision of the element (Wessler, 1988; Menssen et al., 1990).

In tomato, no endogenous transposable elements have been isolated thus far, but tomato lines which carry unstable genes have been recorded (Burdick, 1956; Rick et al., 1956; Hagemann, 1958, 1962; Lesley \& Lesley, 1961, 1963; Seeni \& Gnanam, 1980; Gill, 1983). In none of these cases could the variegated character be unequivocally attributed to the presence of transposable elements. The green-yellow variegated mutant detected by Hagemann (1962) in the $X_{2}\left(=M_{2}\right)$ generation following irradiation of tomato seeds appeared to be a case of reverse variegation. This socalled eversporting mutant was shown to be allelic to the yellow virescent $(y v)$ locus, which is a nuclear gene affecting chloroplast development (Hagemann, 1962; Herrmann \& Hagemann, 1967). The $y v$ locus has been mapped previously on the long arm of chromosome 6 (Robinson \& Rick, 1954) in the proximity of the heterochromatic region bordering the centromere (Khush \& Rick, 1968). The mutant plants were distinguishable by the appearance of yellow sectors of variable size on the otherwise green cotyledons and leaves and by the occurrence of green, variegated and yellow offspring. Because the yellow plants were male sterile, Hagemann has called this mutant allele yellow virescent masculosterilis $\left(y v^{m s}\right)$. Typically, green seedlings became variegated during plant growth. In summary, three phenotypic classes of $y v$ mutants have been recorded including variegated plants, yellow plants being male sterile (Hagemann, 1967; Herrmann \& Hagemann, 1967) and yellow plants with normal fertility (Robinson \& Rick, 1954).

On the assumption that endogenous transposable elements are involved in the instability at the $y v$ locus, this case has been re-investigated. Formerly, the somatic instability was explained in terms of the frequent loss of a centric fragment of chromosome 6 carrying the wild type $y v^{+}$allele or a complementary factor which determined, together with $y v^{m s}$, a green leaf colour (Hagemann, 1963; Herrmann \& Hagemann, 1967). According to this hypothesis, the presence of a fragment in an otherwise recessive homozygote $y v^{m s}$ gives rise to green tissue whereas the loss of this fragment in some cells and their clonal offspring produces yellow sectors or yellow progeny. In this study, cytogenetic evidence is presented that argues against the role of a centric fragment in the variegation. Furthermore, we report new genetic data on the unstable mutation and discuss the possible mechanisms underlying the instability.

\section{Materials and methods}

\section{Plant material}

The seeds of the eversporting mutant $\mathrm{Yv}^{\mathrm{ms}}$ (552184I6 and 552185I6) were kindly provided by R. Hagemann. The features and the origin of the tomato genotypes used are summarized in Table 1. The $y v$ allele, described originally by Robinson \& Rick (1954), has been indicated in the present article as $y v^{s t}$, to emphasize its difference from $y v^{m s}$. All plants were grown in the greenhouse with standard cultivation methods. Genetic segregation ratios were determined by germinating and growing the seedlings in boxes filled with

Table 1 Features and the origin of the tomato genotypes

\begin{tabular}{|c|c|c|c|}
\hline Code & Relevant marker genes & Origin & Reference \\
\hline $\begin{array}{l}2501 / 49 \\
Y_{v^{\mathrm{ms}}}\end{array}$ & $y v^{v g}, y v^{m u t}$ & $\begin{array}{l}\text { Induced by X-rays in the } \\
\text { variety Condine Red }\end{array}$ & Hagemann (1962) \\
\hline LA780 & $y v^{s t}$ & $\begin{array}{l}\text { Spontaneous in asynaptic line } \\
\text { of the variety San Marzino }\end{array}$ & Robinson \& Rick (1954) \\
\hline N118 & Aps- $I^{\prime}$ & $\begin{array}{l}\text { Selected from a cross of the } \\
\text { nematode resistant line USDA } \\
773175-1 \text { to a susceptible line } \\
\text { UC } \times 99 \mathrm{~m}-1\end{array}$ & Ho et al. (1992) \\
\hline L41 & $\begin{array}{l}\text { Deletion of a block of hetero- } \\
\text { chromatin on the long arm of } \\
\text { chromosome } 6, A p s-1^{3}\end{array}$ & $\begin{array}{l}\text { Doubled monohaploid derived } \\
\text { from a pollination of } \\
\text { L. esculentum } \mathrm{L} 121 \text { with } \\
\text { irradiated pollen of } \\
\text { L. pimpinellifolium }\end{array}$ & Ecochard et al. (1969) \\
\hline
\end{tabular}


potting soil. The seedlings were scored approximately 3 weeks after sowing.

\section{Cytological techniques}

For mitotic chromosome studies, the root tips were collected from young seedlings (5-6 weeks old) grown in small plastic pots. The root tips were treated for $4 \mathrm{~h}$ with 0.002 м 8-hydroxyquinoline. The root tips were then fixed in a $3: 1$ solution of ethanol and acetic acid, hydrolysed in $1 \mathrm{~N}$ hydrochloric acid for $8 \mathrm{~min}$ at $60^{\circ} \mathrm{C}$, stained in Feulgen's reagent and gently squashed in a drop of 2 per cent acetocarmine. Both mitotic and meiotic chromosomes were Giemsa-stained according to the procedure of Ramachandran \& Ramanna (1985). In each plant 50-100 somatic and pollen mother cells were analysed. The number of fragments was scored in well-spread metaphase stages in mitotic cells whereas in pollen mother cells, pachytene, metaphase I and anaphase I cells were analysed.

\section{Acid phosphatase isozyme analysis}

Leaf samples were assayed for acid phosphatase (APS) isozyme activity according to Aarts et al. (1991).

\section{Results}

\section{Cytological investigations}

Distribution of fragments. As to the nature of the instability at the $y v$ locus in the so-called eversporting mutant, which is depicted in Fig. 1a, Hagemann proposed that the appearance of the yellow sectors on the green leaves was the result of the frequent loss of a centric fragment of chromosome 6 carrying a wild-type $\mathrm{yv}^{+}$allele or another factor necessary for the expression of $y v^{m s}$ (Hagemann, 1963). According to this hypothesis green tissue but not yellow tissue is expected to carry the centric fragment. To verify this hypothesis we have determined the number of centric fragments in root tips and pollen mother cells (pmc) from 35 plants originating from the original mutant. Among these 35 seedlings, nine carried green cotyledons, 20 variegated and six pure yellow ones. Similar to Hagemann's $(1962,1967)$ observations, all the seedlings with green cotyledons eventually became variegated.

When examining root tip cells, most plants carried fragments in addition to the normal diploid chromosome number $(2 n=2 \mathrm{x}=24)$, their number varying between one and six (Table 2). Upon closer examination, however, it became clear that sometimes two pairs of macro- and microsatellites of chromosome 2 were detached from the main bodies of the chromosomes giving the false impression of the presence of fragments (Fig. 2a). The chromosome 2 origin of the fragments was further confirmed through Giemsa staining of the somatic chromosomes (Fig. 2b). In pollen mother cells, the satellites were not detached from the chromosomes, and centric fragments were identified as such by their capacity to divide during late metaphase I or anaphase I (Fig. 2c). Following the study of pollen mother cells, it was established that the number of centric fragments present in green, variegated and yellow plants varied between zero and three (Table 2). A notable feature was the considerable variation in the size of the fragments ranging from 2 to $3 \mu \mathrm{M}$ to the size of small tomato chromosomes $(5-7 \mu \mathrm{M})$. Thus, regardless of their phenotype, the majority of the plants appeared to possess fragments. Moreover, the number of fragments present in these plants was not related to the proportion of yellow plants detected in their offspring (Table 3 ). These findings argue against the hypothesis of Hagemann who predicted that yellow plants are devoid of fragments and that an inverse relation exists between the number of fragments in a given parent plant and the percentage of yellows in their offspring.

\section{Genetic analysis}

Mutability of the $\mathrm{yv}^{\mathrm{mut}}$ allele and genotype of variegated plants. To explain the conversion from green to yellow in the eversporting mutant we postulated the presence of an unstable $y v$ allele $\left(y v^{m u t}\right)$ which frequently mutates to $y v^{m s}$. This assumption was originally been put forward by Hagemann before he switched to favouring the fragment hypothesis (1962). The occurrence of yellow male sterile plants in the offspring of variegated plants indicated that the newly generated $y v^{m s}$ allele was stably transmitted to the next generation (Table 3 ). The percentage of yellow plants in the selfed progenies of variegated plants varied between 20 and 61 and usually differed from a 3:1 Mendelian ratio (Table 3, Fig. 1b). This variation was most likely due to the chimerical character of the parent plants. As the $y v^{m u t}$ allele frequently mutated to $y v^{m s}, y v^{m u t} / y v^{m s}$ and $y v^{m s} /$ $y v^{m s}$ sectors were expected to arise in the original $y v^{\text {mut }} /$ $\mathrm{yv}^{\mathrm{mut}}$ mutant. In cases where all gametes were derived from $y v^{m u 1} / y v^{m s}$ sectors the maximum percentage of yellow plants among the selfed offspring should be 25 per cent. The selfed progenies consisted, however, of significantly higher percentages, up to 61 per cent, of yellow plants. From this observation it was inferred that, unlike the male sterility of the $y v^{m s} / y v^{m s}$ plants, the $y v^{m s} / y v^{m s}$ sectors contributed to the germinal tissue. Alternatively, the relative high proportion of yellow plants could be the result of mutation events in meiotic tissue. 
Fig. 1 (a) Phenotype of a wild-type (left) tomato plant and a variegated plant of the mutant $\mathrm{Yv}^{\mathrm{ms}}$ (right).

(b) Example of a selfed progeny of a variegated plant with an excess of yellow seedlings.
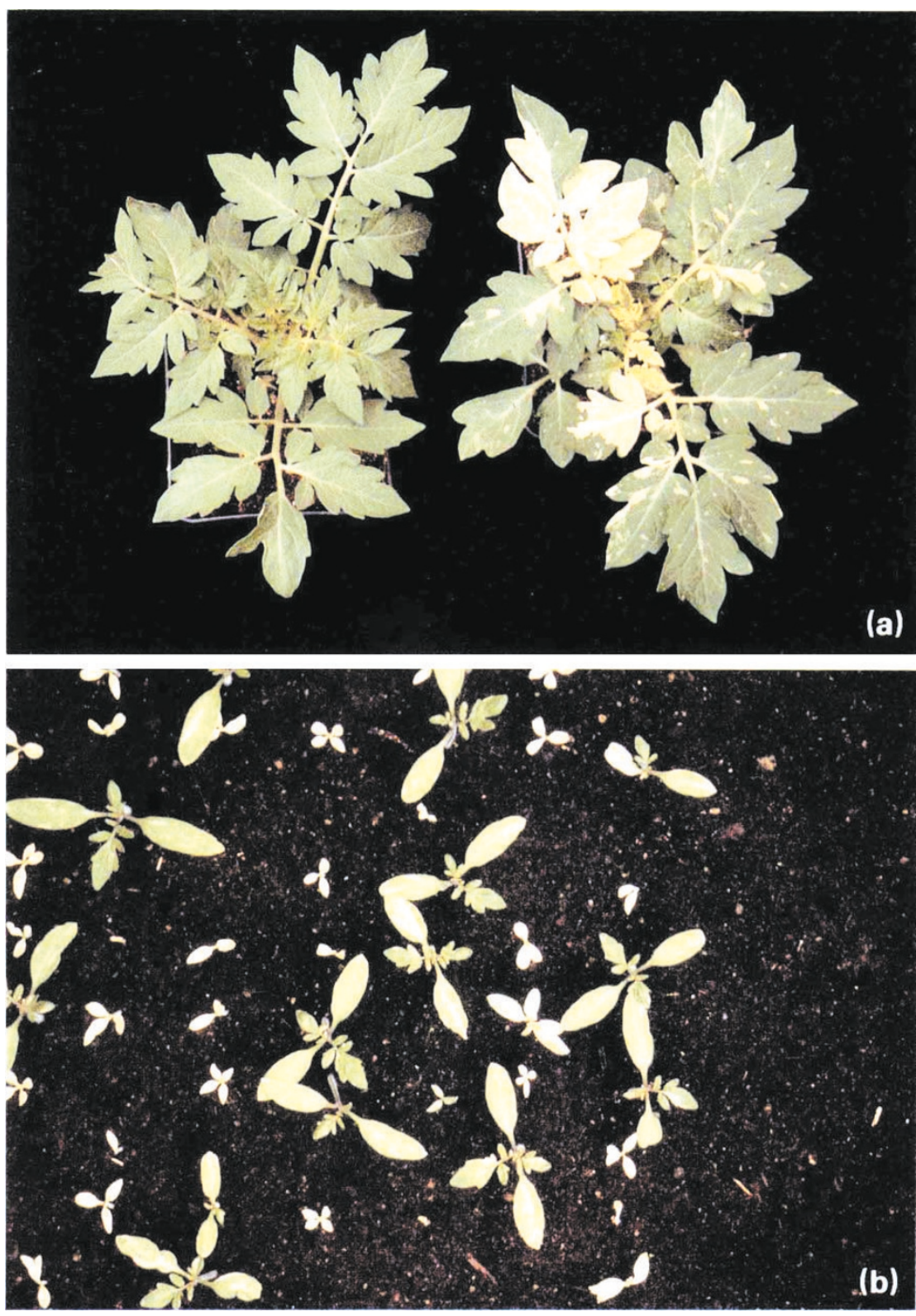

Among the selfed population of the original variegated mutant, early and late spotting plants were identified, the latter by their green cotyledons. These different patterns of expression may indicate a difference in genotype of the variegated plant. In principle, a variegated plant can be composed of two genotypes: $y v^{m u t} / y v^{m u t}$ or $y v^{m u t} / y v^{m s}$. Taking into account that in homozygous $y v^{\text {mut }}$ plants, two simultaneous mutations are needed for the formation of yellow sectors, it is likely that the late spotting plants represented the homozygous $y v^{m u t}$ plants. To test this hypothesis, an attempt was made to deduce the genotype of the variegated plants from the proportion of yellows in their offspring, on the assumption that $y v^{m u t}$ homozygotes are likely to produce yellows in a frequency lower than 25 per cent (the percentage expected for a recessive character) and $y v^{m u t} / y v^{m s}$ heterozygotes in a frequency higher than 25 per cent. The proportion of yellows, however, exceeded 25 per cent in all but one progeny. Apparently, the mutation rate was too high to distinguish parental genotypes by this criterion. Alternatively, the occurrence of early and late spotting plants may point to the presence of newly arisen $y v^{m u t}$ alleles which activated the mutation process early or late in development. These so-called 'changes in state' have been shown to be a characteristic feature of certain 
Table 2 Number of plants with and without centric fragments determined in a selfed population of the $\mathrm{Yv}^{\mathrm{ms}}$ line. The seedlings possessed either green, variegated or yellow cotyledons

\begin{tabular}{lcccccccc}
\hline & \multicolumn{2}{c}{ Green } & & \multicolumn{2}{c}{ Variegated } & & \multicolumn{2}{c}{ Yellow } \\
\cline { 2 - 3 } & Present & Absent & & Present & Absent & & Present & Absent \\
\hline Root tip cells & 7 & 2 & & 16 & 4 & & 3 & 3 \\
Pollen mother cells & 6 & 3 & & 15 & 5 & & 2 & 4 \\
\hline
\end{tabular}
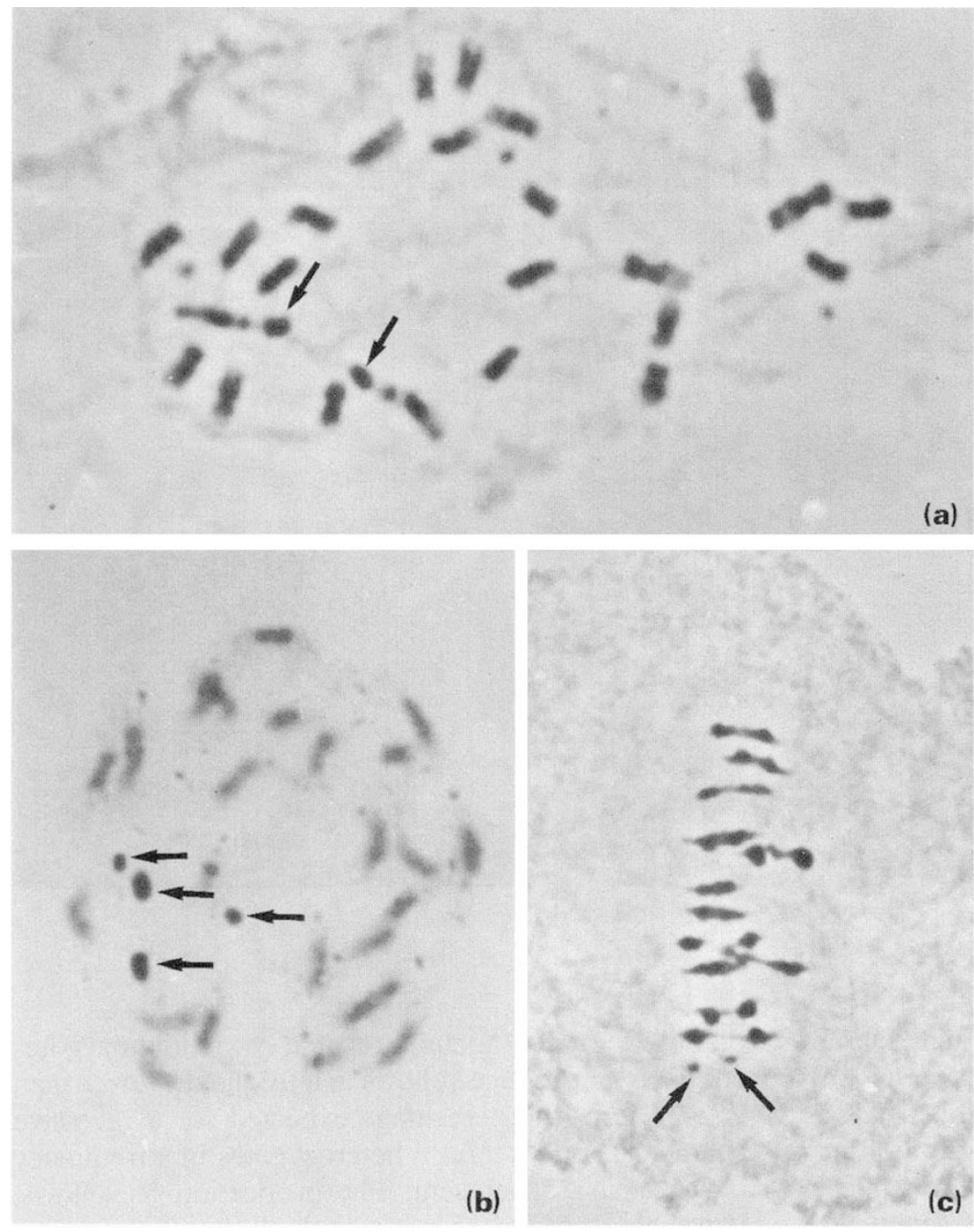

Fig. 2 (a) Feulgen-stained metaphase stage in a root tip cell of the eversporting mutant $\mathrm{Yv}^{\mathrm{ms}}$ showing a pair of nucleolar chromosomes (arrows) each having a large terminal satellite preceded by a smaller one. (b) Giemsastained late prophase stage in a root tip cell of the eversporting mutant showing four darkly-stained fragments (arrows) which are in fact detached satellites. (c) Meiotic metaphase I stage in a mutant showing three fragments, two of which are already dividing at this stage (arrows). One fragment (above) need not be a centric fragment as it is not certain whether it will divide like the others. alleles carrying a transposable element insertion (McClintock, 1948; Fedoroff, 1989). Analysis of this possibility, however, was seriously hampered because of the inability to assign the $y v$ genotype, $y v^{m u t}$ $y v^{m u t}$ or $y v^{m u t} / y v^{m s}$, to individual seedlings.
Direction of mutation. Two types of crosses were made to confirm the direction of mutation in variegated plants. First, variegated plants were crossed to wildtype plants to produce either $y v^{+} / y v^{m u t}$ or $y v^{+} / y v^{m s}$ heterozygotes. Upon selfing the $y v^{+} / y v^{m u l}$ heterozy- 
Table 3 Segregation into variegated and yellow plants in the selfed progenies of 'green' and variegated plants carrying different numbers of fragments

\begin{tabular}{|c|c|c|c|c|c|c|}
\hline \multicolumn{3}{|c|}{ Parent } & \multicolumn{4}{|c|}{ Progeny } \\
\hline $\begin{array}{l}\text { Plant } \\
\text { number }\end{array}$ & Phenotype & $\begin{array}{l}\text { Number of } \\
\text { fragments }\end{array}$ & $\begin{array}{c}\text { Variegated } \\
\left(y v^{m u t}\right)\end{array}$ & $\begin{array}{l}\text { Yellow } \\
\left(y v^{m s}\right)\end{array}$ & $\% y v^{m s}$ & $\begin{array}{l}\text { Mean } \\
\% y v^{m s}\end{array}$ \\
\hline 3 & Variegated & 0 & 174 & 142 & 45 & \\
\hline 5 & Variegated & 0 & 554 & 200 & 27 & \\
\hline 11 & Variegated & 0 & 176 & 225 & 56 & \\
\hline 25 & Variegated & 0 & 224 & 180 & 45 & \\
\hline 40 & Variegated & 0 & 237 & 162 & 41 & \\
\hline 4 & Variegated & $1(1 \mathrm{~s})$ & 207 & 227 & 52 & \\
\hline 23 & Variegated & $1(1 s)$ & 246 & 169 & 41 & \\
\hline 1 & Variegated & $2(2 s)$ & 190 & 142 & 43 & 47 \\
\hline 6 & Variegated & $2(1 m+2 s)$ & 554 & 200 & 27 & \\
\hline 13 & Variegated & $2(1 l+1 s)$ & 239 & 195 & 45 & \\
\hline 15 & Variegated & $2(11+1 s)$ & 246 & 169 & 41 & \\
\hline 27 & Variegated & $2(2 s)$ & 146 & 194 & 57 & \\
\hline 29 & Variegated & $2(1 \mathrm{l}+1 \mathrm{~s})$ & 222 & 225 & 50 & \\
\hline 31 & Variegated & $2(11+1 s)$ & 200 & 198 & 50 & \\
\hline 10 & Variegated & $3(31)$ & 185 & 287 & 61 & \\
\hline 14 & Variegated & $3(3 s)$ & 276 & 94 & 25 & \\
\hline 24 & Variegated & $3(2 m+1 s)$ & 192 & 230 & 55 & \\
\hline 26 & Variegated & $3(11+2 s)$ & 170 & 138 & 45 & \\
\hline 30 & Variegated & $3(1 m+2 s)$ & 344 & 84 & 20 & \\
\hline 6 & Green & 0 & 97 & 115 & 54 & 41 \\
\hline 8 & Green & 0 & 358 & 122 & 25 & \\
\hline 38 & Green & 0 & 205 & 82 & 29 & \\
\hline 39 & Green & $1(1 \mathrm{~m})$ & 211 & 201 & 49 & \\
\hline 41 & Green & $1(1 \mathrm{~s})$ & 287 & 105 & 27 & \\
\hline 21 & Green & $2(1 \mathrm{l}+1 \mathrm{~s})$ & 318 & 159 & 33 & 38 \\
\hline 9 & Green & $3(1 m+2 s)$ & 312 & 131 & 30 & \\
\hline 32 & Green & $3(2 m+1 s)$ & 374 & 164 & 30 & \\
\hline & & & & & & 30 \\
\hline
\end{tabular}

1: large fragment; m: medium sized fragment; s: small fragment.

gotes, a variable number of yellow plants segregated in addition to the wild-type green and variegated plants. This observation was compatible with $y v^{m u t}$ having mutated to $y v^{m s}$ during plant development. Secondly, a variegated plant was crossed to LA780 $\left(y v^{s t} / y v^{s t}\right)$ to produce a variegated $y v^{m u t} / y v^{s t}$ heterozygote. This heterozygote was then used to pollinate yellow $y v^{m s} / y v^{m s}$ plants. In the progeny, variegated $y v^{m u t} / y v^{m s}$ and yellow $y v^{m s} / y v^{s t}$ plants were expected to segregate, the latter being male fertile as $y v^{s t}$ is dominant over $y v^{m s}$. Among the yellow progeny, however, we found 18.5 per cent male sterile plants $\left(y v^{m s} / y v^{m s}\right)$ which indicated that the $y v^{m u t}$ allele had mutated to $y v^{m s}$.

Reduced transmission of the mutant alleles $\mathrm{yv}^{\mathrm{mut}}$ and $\mathrm{yv}^{\mathrm{ms}}$. Previously, Hagemann had observed that $\mathrm{F}_{2}$ populations originating from crosses between wildtype $y v^{+}$tomato lines and variegated plants, displayed a marked deficit of yellow and variegated plants (Hagemann, 1962). That is, wild-type green plants occurred at a higher rate than the 75 per cent expected for a dominant character. Similarly, we observed a deficit of 
Table 4 Segregations into variegated and yellow plants in $\mathrm{F}_{1}, \mathrm{~F}_{2}, \mathrm{BC}_{1}$ and $\mathrm{BC}_{2}$ populations derived from crosses between three variegated plants and LA780

\begin{tabular}{|c|c|c|c|c|c|c|c|c|c|}
\hline \multicolumn{2}{|c|}{ Cross } & \multicolumn{2}{|c|}{$F_{1}$ progeny } & \multicolumn{2}{|c|}{$F_{2}$ progeny } & \multicolumn{2}{|c|}{$\mathrm{BC}_{1}$ progeny } & \multicolumn{2}{|c|}{$\mathrm{BC}_{2}$ progeny } \\
\hline $\begin{array}{c}\text { Parents } \\
(\text { female } \times \text { male })\end{array}$ & Phenotype & Variegated & Yellow & Variegated & Yellow & Variegated & Yellow & Variegated & Yellow \\
\hline LA780 × VG32 & Yellow $\times$ variegated & 58 & 54 & 1492 & $955(5)^{\dagger}$ & 105 & $955(2)^{\dagger}$ & 85 & $85(1)^{\ddagger}$ \\
\hline $\mathrm{LA} 780 \times \mathrm{VG} 40$ & Yellow $\times$ variegated & 19 & 26 & 313 & $535(2)^{\dagger}$ & 114 & $519(1)^{\dagger}$ & & \\
\hline BOY $149 \times$ LA780 & Variegated $\times$ yellow & 137 & 137 & 1743 & $1728(9)^{\dagger}$ & 6 & $43(1)^{\dagger}$ & & \\
\hline
\end{tabular}

${ }^{\dagger}$ Number of variegated $F_{1}$ plants that have been selfed or backcrossed to LA780 using LA780 as female parent.

${ }^{\ddagger}$ Number of variegated $\mathrm{BC}_{1}$ plants that have been crossed to LA780 using LA780 as female plant.

mutant phenotypes in most $F_{2}$ populations derived from crosses with ten different tomato $y v^{+}$genotypes. This finding suggested that the instability at the $y v$ locus was not autonomously controlled but that a second factor, needed for the expression of the instability, was segregating in these $F_{2}$ populations. Under this assumption, the original variegated mutant should be homozygous for this factor as wild-type green plants have not been found after selfing. Accordingly, individuals having a green phenotype should appear due to the absence of the second factor, although their genotype is homozygous $y v^{m u t}$. It was not possible to test this assumption directly in the respective $F_{2}$ populations as no means were available to determine the genotype of the individual plants. Instead, three variegated plants were crossed to LA780 $\left(y v^{s t} / y v^{s t}\right)$ and their backcross and selfed progenies screened for the occurrence of stable green plants (Table 4). As such green plants were not found, it seems that $y v^{m u t}$ was autonomously controlled and that the deficit in mutant phenotypes was not the result of the segregation of an additional factor. An alternative possibility would be that the $y v^{s t}$ was also homozygous for the postulated autonomous element and segregation does not occur in the $F_{2}$ populations.

Following these observations, the question arose as to which mechanism induced the shortage of mutant phenotypes in $\mathrm{F}_{2}$ populations. For example, competition between gametes carrying wild-type and mutant $y v$ alleles (certation) would result in a shortage of mutant phenotypes. Also, a reduced viability of $y v$ seedlings would show the same effect. To test these possibilities, the Aps-I isozyme marker, which is absolutely linked to the $y v$ locus on chromosome 6 (MedinaFilho, 1980; Weide et al., 1993), was used as an aid for identifying the different $y v$ alleles in two crosses. The first $\mathrm{F}_{2}$ population to be analysed for its Aps-I genotype was derived from a cross between a variegated plant $\left(A p s-I^{+} \mid A p s-I^{+}, y v^{m u t} /\right.$.) and a tomato genotype $\mathrm{N} 118$ (Aps-1 $1^{\prime} / A p s-1^{l}, y v^{+} / y v^{+}$; Ho et al., 1992). This population showed a marked deficit in mutant phenotypes. The second $F_{2}$ population was derived from a cross of a variegated plant $\left(A p s-1^{+}\right)$ $A p s-1^{+}, y v^{m u t} /$.) to L41 (Aps-1 $\left.I^{3} / A p s-1^{3}, y v^{+} / y v^{+}\right)$, a tomato genotype in which a large block of heterochromatin, that is positioned close to the centromere of chromosome 6, is deleted (Ecochard et al., 1969). In this population mutant phenotypes segregated in a normal ratio. From the latter cross, two backcross populations with LA780 $\left(\right.$ Aps- $\left.I^{+} / A p s-I^{+}, y v^{s t} / y v^{s t}\right)$ were also analysed. In both $\mathrm{F}_{2}$ populations, green plants carried at least one copy of the Aps- $I^{\prime}$ allele (cross A in Table 5) or the Aps- $1^{3}$ allele (cross B in Table 5), indicating that, as expected, the wild-type $y v^{+}$ allele was present. Furthermore, the frequency of the Aps $-1^{+}$allele among the green plants was consistent with the ratios estimated from the frequency of variegated and yellow $\mathrm{F}_{2}$ plants. Similarly, in the 57 plants of the two backcross populations $\left(y v^{+} / y v^{m u t}, A p s-1^{3} / A p s^{-}\right.$ $I^{+} \times y v / y v, A p s-1^{+} /$Aps $\left.-I^{+}\right)$the 39 green plants carried the Aps-1 $1^{+}$and the Aps- $1^{3}$ alleles whereas the 18 yellow plants were all homozygous $A p s-I^{+}$. These observations excluded the possibility that a reduced viability of mutant seedlings caused the distorted segregation ratios (Table 5), as the failure of mutant seeds to develop in plants does not influence the frequency of mutant alleles produced by the parent. In other words, two-thirds of the green plants will carry a mutant allele, irrespective of the number of mutants in a population. Clearly this was not the case in the progenies tested, so we conclude that certation caused the distorted segregation data. Finally, these data argued again against the possibility that a second factor was needed to express the variegation.

Reversion. As insertion mutations usually produce wild-type revertant alleles through the precise excision of the element, we have screened progenies of varie- 
Table 5 Distribution of several Aps- 1 alleles among green, variegated and yellow $\mathrm{F}_{2}$ plants derived from the cross $\mathrm{N} 118 \times \mathrm{Yv}^{\mathrm{ms}}(\mathrm{A})$ and $\mathrm{L} 41 \times \mathrm{Yv}^{\mathrm{ms}}(\mathrm{B})$

\begin{tabular}{|c|c|c|c|c|c|c|c|c|c|}
\hline \multirow{2}{*}{$\begin{array}{l}\mathrm{A} \\
y v\end{array}$} & \multicolumn{4}{|c|}{ Aps-1 } & \multirow{2}{*}{$\begin{array}{l}\mathrm{B} \\
y v\end{array}$} & \multicolumn{4}{|c|}{ Aps- 1} \\
\hline & $1 / 1$ & $+/ 1$ & $+1+$ & Total & & $3 / 3$ & $+/ 3$ & $+1+$ & Total \\
\hline$y v^{+} /$ & 44 & 36 & 0 & 80 & $y v^{+} /$ & 15 & 19 & 0 & 34 \\
\hline$y v^{\text {mut }} /$ & 0 & 0 & 6 & 6 & $y v^{m u t} /$. & 0 & 0 & 4 & 4 \\
\hline$y v / y v$ & 0 & 0 & 3 & 3 & $y v / y v$ & 0 & 0 & 7 & 7 \\
\hline Total & 44 & 36 & 9 & 89 & Total & 15 & 19 & 11 & 45 \\
\hline
\end{tabular}

gated plants for the occurrence of stable green offspring. Selfed progenies consisting of approximately 7000 seeds derived from 27 yellow $y v^{m s} / y v^{s t}$ heterozygotes were examined for the same purpose. Among the selfed progenies derived from variegated plants wildtype green plants were not identified. In contrast, the progeny of one yellow $y v^{m s} / y v^{s t}$ plant consisted of 125 variegated and 79 yellow seedlings, originating from seeds of a cluster in a higher part of the plant whereas the lower clusters only produced yellow progeny. Apparently, during a particular stage of development a reversion from $y v^{m s}$ to $y v^{m u t}$ had occurred in the germinal layer.

The mutant phenotype is occasionally expressed in $F_{I}$ plants. Surprisingly, one variegated (BOY149) and three yellow male sterile plants were observed among a population of $1671 \mathrm{~F}_{1}$ plants originating from crosses between a wild-type $y v^{+}$genotype carrying an $A d h-1$ null mutation (B15-1-8; Wisman et al., 1991) and variegated plants. Their true hybrid nature was demonstrated by the presence of the maternally derived $A d h$ 1 null allele and a $5 \mathrm{~kb}$ polymorphic EcoRI fragment. From these findings it was speculated that the mutant alleles $y v^{m u t}$ and $y v^{m s}$ are capable of changing the $y v^{+}$ allele to $y v^{m u t}$ or $y v^{m s}$ when present in the same nucleus. Alternatively, a mitotic crossing over event that had occurred very early in embryo development could explain this phenomenon.

Once the first yellow sectors had appeared on the third and fourth leaf of the variegated $F_{1}$ plant BOY 149 , its phenotype was indistinguishable from other variegated plants. Three cuttings derived from the variegated part of plant BOY 149 were grown to flowering plants. When selfed or backcrossed to LA780, segregation into variegated and yellow male sterile plants occurred indicating that the change at the $y v^{+}$locus was heritable (Table 6). The segregation ratio was not significantly different from $3: 1$ in the selfed population or from $1: 1$ in the backcross population, as if BOY149 was a $y v^{m u t} / y v^{m s}$ heterozygote in which the $y v^{m u t}$ allele did not mutate to $y v^{m s}$. A comparable low mutation rate of the $y v^{m u t}$ allele was also observed in the selfed offspring of six variegated BOY149 descendants in which the proportion of yellow male sterile plants was either 25 per cent or was slightly higher than 25 per cent.

\section{Discussion}

Previously, the appearance of yellow spots on a green background was explained by the loss of an extra chromosomal fragment (Hagemann, 1963; Herrmann \& Hagemann, 1967). By analysing the selfed offspring of the original mutant, we have now shown that no relations exist between the phenotype of a plant and the presence of extra chromosomal fragments. For this reason, it appears incorrect to ascribe the mutability of the mutant line to the frequent loss of the centric fragments (Hagemann, 1963; Herrmann \& Hagemann, 1967). Furthermore, in Hagemann's model it is quite difficult to explain how a reversion from yellow to variegated can take place, an event we have recorded in our material.

The phenotypic switch from green to yellow in the eversporting mutant $\mathrm{Yv}^{\mathrm{ms}}$ and the appearance of yellow plants in its offspring, suggested the presence of an unstable allele $\left(y v^{m u t}\right)$ that frequently mutates to recessive yellow $\left(y v^{m s}\right)$. That the direction of mutation was from $y v^{m u t}$ to $y v^{m s}$ was confirmed by the appearance of yellow male sterile plants in populations derived from $y v^{+} / y v^{m u t}$ and $y v^{m u t} / y v^{s t}$ heterozygotes. The mutation rate appeared to be autonomously controlled and very high as was inferred from the high percentage of yellow offspring.

The unusually high frequency of mutation invited speculation about the possible involvement of transposable elements in the instability. As the direction of mutation was from dominant green to recessive yellow, the mutant line represented an example of reverse variegation. This less common phenomenon has been earlier associated with transposable elements (Nevers et al., 1986). An example is the unstable mutation 
Table 6 Segregation into variegated and yellow plants in $F_{2}, F_{3}$ and backcross populations with LA780 obtained from the variegated $F_{1}$ plant BOY 149

\begin{tabular}{|c|c|c|c|c|c|c|}
\hline \multirow[b]{2}{*}{ Parent } & \multicolumn{3}{|c|}{ Selfed progeny } & \multicolumn{3}{|c|}{$\mathrm{BC}_{1}$ progeny } \\
\hline & $\begin{array}{c}\text { Variegated } \\
\left(y \nu^{m u t}\right)\end{array}$ & $\begin{array}{c}\text { Yellow } \\
\left(y v^{\prime n s}\right)\end{array}$ & $\% y v^{m s}$ & $\begin{array}{l}\text { Variegated } \\
\left(y v^{m u t}\right)\end{array}$ & $\begin{array}{l}\text { Yèllow } \\
\left(y v^{m s}\right)\end{array}$ & $\% y v^{m s}$ \\
\hline BOY $149 \dagger$ & 257 & 111 & 30 & 298 & 281 & 49 \\
\hline BOY 149-1 & 152 & 88 & $37 \ddagger$ & 78 & 100 & 56 \\
\hline BOY $149-2$ & 167 & 113 & $40 \ddagger$ & 47 & 92 & $66 \ddagger$ \\
\hline BOY 149-3 & 127 & 46 & 27 & 106 & 93 & 47 \\
\hline BOY 149-4 & 270 & 187 & $41 \ddagger$ & 89 & 108 & 55 \\
\hline BOY $149-5$ & 52 & 30 & 37 & 127 & 137 & 52 \\
\hline BOY 149-6 & 116 & 90 & $44 \ddagger$ & 119 & 196 & $62 \ddagger$ \\
\hline
\end{tabular}

${ }^{\dagger}$ Six different variegated $F_{2}$ plants of BOY 149 were selfed or backcrossed to LA780 using LA780 as male parent.

־Segregations significantly different from $3: 1$ in selfed progenies or from $1: 1$ in backcross progenies, $P<0.01$.

(Y18m) of soybean, which showed similarities in phenotype and genetic behaviour to the unstable $y \mathrm{v}$ mutant. In case of $Y 18 \mathrm{~m}$, the patterns of reverse variegation were attributed to the activity of a transposable element (Peterson \& Weber, 1969; Chandlee \& Vodkin, 1989). One important difference with the unstable $y v$ mutation was the appearance of stable wild-type revertants among the selfed offspring of $Y 18 \mathrm{~m}$. Such revertants have not been found in $y v^{m u t}$ offspring. Moreover, another characteristic feature of transposable element insertions apparently missing from the unstable $y v$ mutant was the production of alleles with new phenotypes. The $y v^{m u t}$ allele mutated frequently to $y v^{m s}$ but it seemed that the new alleles were identical in conditioning male sterility $\left(y v^{m s}\right)$, a character that is not necessarily associated with a yellow virescent condition.

The observation that the phenotype of the recessive $y v$ alleles was sometimes expressed in $\mathrm{F}_{1}$ hybrids may indicate that a transposable element present in the mutant $y v$ allele inserted into the homologous wildtype $y v^{+}$allele, a phenomenon that seems to occur rarely in petunia insertional alleles (Bianchi et al., 1978). Assuming that the frequent transposition of an element from a nearby site into the $y v$ locus gave rise to yellow tissue, the observed stability of the $y v^{m s}$ allele should not be expected, as the $y v^{m s}$ allele is supposed to carry the insertion. To date only one example of a comparable situation has been described in maize where, in the absence of $A c$, wild-type expression of the waxy gene occurred, although a $D s$ element was inserted in the upstream sequences. When $A c$ was present, however, mutant sectors arose as a result of intragenic transposition events, thereby generating stable and unstable germinal derivatives (Weil et al., 1992). Thus, although the involvement of a transposable element in the instability at $y v$ cannot be ruled out, other mechanisms deserve serious attention.

Thus far, the molecular basis of instances of genetic instability other than those implemented by transposable elements is hardly known. Examples in plant and animal systems do show that instability can be explained in terms of the reversible alteration in chromatin structure rather than in DNA sequence (Reuter \& Spierer, 1992; Jablonka et al., 1992). It is recognized that the components of chromatin and their conformation influence the functional state of the gene. Variable factors are the timing of replication during the S-phase, the DNAse sensitivity and the degree of condensation and methylation (Jablonka et al., 1992). The latter two, which are probably not independent from each other, have been put forward as mechanisms underlying variegation. In Drosophila the variegated expression of genes was thought to be the result of the extension of the highly condensed state of heterochromatin into the gene (Henikoff, 1990). The same model was proposed to explain the instability at alleles of the sulfurea locus of tomato which is located in the heterochromatic region of chromosome 2 (Hagemann, 1969; Wisman et al., 1993). In transgenic tobacco plants the variable expression of the maize $A 1$ gene correlated with the methylation of its promoter sequences (Meyer et al., 1993). It can be envisaged that the instability at $y v$ is caused by a similar mechanism affecting chromatin structure because of its position in a heterochromatic region. Moreover, the $y v$ mutation was induced by 
$\mathrm{X}$-ray treatment that was known to cause chromosomal rearrangements. Hence, a change in the position of $y v$ relative to heterochromatin could be responsible for its unstable expression.

In homozygous $y v^{m s} / y v^{m s}$ plants two characters were expressed simultaneously: yellow leaves and male sterility. It could be argued that the male sterility results from a second mutation in a gene that is required for male fertility and thus two different genes are affected in the $y v^{m s}$ plants. If so, the $m s$ gene must be closely linked to $y v$ as we have not been able to separate these two characters. If a spreading of heterochromatin into the $y v$ locus could explain the instability and, in addition, the $m s$ locus is located in between the heterochromatic region and $y v$, then the two loci would be always inactivated simultaneously. A second explanation could be that the male sterility is a pleiotropic effect of the $y v^{m s}$ allele. Some support for this hypothesis might come from the observation that seed set can also be poor on $y v^{s t}$ plants which are in less favourable conditions. Thus, the $y v^{m s}$ allele could condition a more extreme phenotype than the $y v^{s t}$ allele.

\section{Acknowledgements}

We thank Hilda Kranendonk for assistance. We are indebted to Professors R. Hagemann, M. Koornneef and Drs P. Zabel and T. Gerats for critical reading of the manuscript. This research was supported by The Netherlands Foundation for Biological Research (BION) with financial aid from The Netherlands Organisation for Scientific Research (NWO).

\section{References}

AARTS, J. M. M. J. G., HONTELEZ, J. G. J., FISCHER, P., VERKERK, R., VAN KAMmen, A. AND ZABEL, P. 1991. Acid phosphatase-l, a tightly linked molecular marker for root-knot nematode resistance in tomato: from protein to gene, using PCR and degenerate primers containing deoxyinosone. Plant Mol. Biol., 16, 647-661.

BIANCHI, F., CORNELISSEN, P. T. J., GERATS, A. G. M. AND HOGERVORST, J. M. w. 1978. Regulation of gene action in Petunia hybrida: unstable alleles of a gene for flower colour. Theor. Appl. Genet., 53, 157-167.

BRINK, R. A. 1973. Paramutation. Ann. Rev. Genet., 7, $129-152$

BURDICK, A. B. 1956. Irradiation induced genetic instabilities. Tomato Genet. Coop. Rep., 6, 8-9.

CHANDLEE, J. M. AND VODKIN, L. o. 1989. Unstable genes affecting chloroplast development in soybean. Devel. Genet., 10, 532-541.

ECOCHARD, R., RAMANNA, M. S. AND VAN NETTANCOURT, D. 1969. Detection and cytological analysis of tomato haploids. Genetica, 40, 181-190.
FEDERofF, N. 1989. Maize transposable elements. In: Berg, D. E. and Howe, M. M. (eds) Mobile DNA, pp. 375-412. American Society for Microbiology, Washington.

GILL, B. S. 1983. Tomato cytogenetics - a search for new frontiers. In: Swaminathan, M. S., Gupta, P. and Sinha, U. (eds) Cytogenetics of Crop Plants, pp. 547-480. Macmillan, India.

HAGEMANN, R. 1958. Somatische Konversion bei Lycopersicon esculentum Mill Z. Vererbl., 89, 587-631.

HaGemann, R. 1962. Instability at the $y v$ locus. Tomato Genet. Coop. Rep., 12, 27-28.

hagemann, R. 1963. Die Cytogenetische Ursache für das Auftreten einer Grün-Gelb-Scheckung bei der Tomate. Züchter, 33, 282-284.

HAGEMANN, R. 1967. Über eine immerspaltende $y v$ Mutantenlinie von Lycopersicon esculentum Mill 1. Genetische Untersuchungen. Biol. Zbl. (Suppl.), 86, 163-180.

HAGEMANN, R. 1969. Somatic conversion (paramutation) at the sulfurea locus of Lycopersion esulentum Mill. III. Studies with trisomics. Can. J. Genet. Cytol., 11, 346-358.

HAGEMANN, R. AND SNOAD, B. 1971. Paramutation (somatic conversion) at the sulfurea locus of Lycopersicon esculentum. V. The localisation of Sulf. Heredity, 27, 409-418.

HENIKOFF, S. 1990. Position-effect variegation after 60 years. Trends in Genetics, 6, 422-426.

HERRMANN, F. AND HAGEMANN, R. 1967. Über eine immerspaltende $y v$-Mutantenlinie von Lycopersicon esculentum Mill 2. Cytogenetische. Untersuchungen an gescheckten Pflanzen. Biol. Zbl. (Suppl.), 86, 181-209.

HO, J., WEIDE, R., MA, H. M., WORDRAGEN, M. F., LAMBERT, K. N., KOORNNEEF, M., ZABEL, P. AND WILLIAMSON, V. M. 1992. The root-knot nematode resistance gene $(M i)$ in tomato: construction of a molecular linkage map and identification of dominant cDNA markers in resistant genotypes. Plant Journal, 2, 971-982.

JABLONKA, E., LACHMANN, M. AND LAMBS, M. J. 1992. Evidence, mechanisms and models for the inheritance of acquired characters. J. Theor. Biol., 158, 245-268.

KHUSH, G. S. AND RICK, C. M. 1968. Cytogenic analysis of the tomato genome by means of induced deficiencies. Chromosoma, 23, 452-484.

KIRK, J. T. O. AND TILNEY-BASSETT, R. A. E. 1978. The Plastids. Elsevier/North-Holland Biomedical, Amsterdam.

LESLEY, J. W. AND LESLEY, M. M. 1961. The cytogenetics of 'flaked', a variegation in tomato affecting two cell layers. Genetics, 46, 831-844.

LESLEY, M. M., LESLEY, J. W. AND SOOST, R. K. 1963. Variegation initiated by a dominant allele in the tomato. Genetics, $\mathbf{4 8}$, 943-955.

McClintock, B. 1948. Mutable loci in maize. Carn. Inst. Year Book, 47, 155-169.

MARTINEZ-ZAPATER, J. M., GILl, P., CAPEL, J. AND SOMERVILLE, C. 1992. Mutation at the Arabidopsis CHM locus promotes rearrangements of the mitochondrial genome. Plant Cell, 4, 889-899.

MEDINA-FILHO, H. P. 1980. Linkage of Aps-1, $M i$ and other markers on chromosome 6. Tomato Genet. Coop. Rep., 30, 26-28. 
MENSSEN, A., HÖHMANN, S., MARTIN, W., SCHNABLE, P. S., PETERSON, P. A., SAEDLER, H. AND GIERL, A. 1990. The En/Spm transposable element of Zea mays contains splice sites at the termini generating a novel intron from a $\mathrm{dSpm}$ element in the $A 2$ gene. EMBOJ., 9, 3051-3057.

MEYER, P., HEIDMANN, I. AND NIEDENHOF, I. 1993. Differences in DNA-methylation are associated with a paramutation phenomenon in transgenic petunia. Plant Journal, 4, 89-100.

NEVERS, P., SHEPHERD, N. S. AND SAEDLER, H. 1986. Plant transposable elements. Adv. Bot. Res., 12, 103-203.

PETERSON, P. AND WEBER, C. R. 1969. An unstable locus in soybean. Theor. Appl. Genet., 39, 156-162.

RAMACHANDRAN, C. AND RAMANNA, M. S. 1985. Giemsa c-banding technique for the study of structure and pairing behaviour of isochromosomes of tomato. Tomato Genet. Coop. Rep., 30, 25.

REUTER, G. AND SPIERER, P. 1992. Position effect variegation and chromatin proteins. BioEssays, 14, 605-612.

RICK, M. R., THOMPSON, E. A. AND BRAUER, O. 1956. Genetics and development of an unstable chlorophyll deficiency in Lycopersicon esculentum. Am. J. Bot., 46, 1-11.

ROBINSON, R. W. AND RICK, M. R. 1954. New tomato seedling characters and their linkage relationships. J. Hered., 54, 241-247.
SEENI, S. AND GNANAM, A. 1981, In vitro regeneration of chlorophyll chimeras in tomato (Lycopersicon esculentum). Can. J. Bot., 59, 1941-1943.

WEIDE, R., WORDRAGEN, M. F., KLEIN LANKHORST, R., VERKERK, R., HANHART, C., LIHARSKA, T., PAP, E., STAM, P., ZABEL, P. AND KOORNNEEF, M. 1993. Integration of the classical and molecular linkage maps of tomato chromosome 6. Genetics, 135, 1175-1186.

WEIL, C. F., MARILLONNET, S., BURR, B. AND WESSLER, S. R. 1992. Changes in state of the $W x-m 5$ allele of maize are due to intragenic transposition of Ds. Genetics, 130, 175-185.

WESSLER, S. 1988. Phenotypic diversity mediated by the maize transposable elements $A c$ and Spm. Science, 241, 399-405.

WISMAN, E., KOORNNEEF, M., CHASE, T., LIFSCHYTZ, E., RAMANNA, M. S. AND ZABEL, P. 1991. Genetic and molecular characterization of an Adh-1 null mutant in tomato. Mol. Gen. Genet., 226, 120-128.

WISMAN, E., RAMANNA, M. S. AND KOORNNEEF, M. 1993. Isolation of a new paramutagenic allele of the sulfurea locus in the tomato cultivar Moneymaker following in vitro culture. Theor. Appl. Genet., 87, 289-294. 